\title{
Access to marriage and reproduction among migrants in Antwerp and Stockholm. A longitudinal approach to processes of social inclusion and exclusion, 1846-1926
}

\section{Paul Puschmann, Per-Olof Grönberg, Reto Schumacher \& Koen Matthijs}

To cite this article: Paul Puschmann, Per-Olof Grönberg, Reto Schumacher \& Koen Matthijs (2014) Access to marriage and reproduction among migrants in Antwerp and Stockholm. A longitudinal approach to processes of social inclusion and exclusion, 1846-1926, The History of the Family, 19:1, 29-52, DOI: 10.1080/1081602X.2013.796889

To link to this article: http://dx.doi.org/10.1080/1081602X.2013.796889

Published online: 08 Jul 2013.

Submit your article to this journal

Џ Article views: 197

Q View related articles $\square$

View Crossmark data $\asymp$

Citing articles: 2 View citing articles $₫$ 


\title{
Access to marriage and reproduction among migrants in Antwerp and Stockholm. A longitudinal approach to processes of social inclusion and exclusion, 1846-1926
}

\author{
Paul Puschmann ${ }^{\mathrm{a} *}$, Per-Olof Grönberg ${ }^{\mathrm{b}}$, Reto Schumacher ${ }^{\mathrm{c}}$ and Koen Matthijs ${ }^{\mathrm{a}}$ \\ ${ }^{a}$ KU Leuven, Family and Population Studies (FaPOS), Centre for Sociological Research, Leuven, \\ Belgium; ${ }^{b}$ Umeå University, Centre for Population Studies, Umeå, Sweden; ${ }^{c}$ Institute for \\ Demographic and Life Course Studies, Geneva, Switzerland
}

(Received 17 October 2012; final version received 15 April 2013)

\begin{abstract}
A longitudinal approach is used to describe and explain processes of social inclusion and exclusion among different groups of migrants in Antwerp and Stockholm (18461926), in terms of access to marriage and reproduction. In this way we want to get a better idea about the factors which facilitated or hampered the social inclusion of migrants upon arrival in two different Western European port cities. The results of the discrete time event history analyses show that social inclusion of migrants was easier in Antwerp and became easier over time, while in Stockholm it was more difficult and became even more complicated over time. This finding might be interpreted as the result of greater societal openness in Antwerp, as the Belgian port-city's economic success depended largely upon foreigners and international trade. Higher odds for social inclusion in Antwerp might also have been related to differences in the chances of finding an urban niche, which in turn might have been a result of disparities in economic and demographic growth. Most likely it was a combination of differences in the local opportunity structure and the level of societal openness. Furthermore, it was found that region and place of birth, age at arrival, historical time period, and, in the case of Stockholm, gender and social class had an important impact on the chances of successful inclusion.
\end{abstract}

Keywords: migration; social inclusion; social exclusion; family formation; marriage; reproduction; urban growth; port cities

\section{Migration and social inclusion and exclusion in Western European cities, 1846-1926}

In the course of the nineteenth century Western European cities started to attract more and more migrants. According to estimations made by Jan Lucassen and Leo Lucassen, the total number of urban in-migrants in Western European cities with more than 10,000 inhabitants increased from about 13 million in the period 1800-1850 to 42 million in the latter part of the nineteenth century (Lucassen \& Lucassen, 2009, p. 362). The largest part of these urban in-migrants were still recruited from within the direct rural vicinity of the city (Moch, 2003; Pooley \& Turnbull, 1997), but the numbers of international migrants in Western European cities started to rise steadily (Lucassen, 2005; Lucassen \& Lucassen, 2009). Especially port cities attracted large numbers of migrants with various socio-cultural and geographic backgrounds (Lee \& Lawton, 2002).

*Corresponding author. Email: Paul.Puschmann@ soc.kuleuven.be 
The causes of increased migration towards Western European cities are well-known. On the one hand, agricultural crises, population pressure and the gradual destruction of the putting-out system drove more and more peasants out of the countryside; on the other hand, cities became gradually an ever more attractive environment, as urban industry offered more permanent employment than agriculture and the putting-out system (Lee, 1999; Moch, 2003). Moreover, as industrialization advanced, the working conditions of factory laborers improved (more rights, less working hours, better payment, etc.), through which industrial employment became more popular. At the same time, living conditions in cities improved as urban areas were reorganized and decent sewers and water pipes were installed. Last but not least, the extension of infrastructure in the form of tram and train connections facilitated the movement from the countryside to the city and from one country to another and allowed urban dwellers to reach their workplace in an easier and faster way (Hochstadt, 2002; Moch, 2003).

Whereas the causes of increased urban in-migration in the latter part of the nineteenth and early twentieth century are well-known, the fate of urban newcomers is more debatable. Inspired by the Chicago School of Sociology (Park, 1928; Park \& Burgess, 1925) and its adherents (e.g. Bouman \& Bouman, 1955; Handlin, 1951), a series of scholars have looked at the adaptation process of urban in-migrants in Western European cities as a dramatic scenario, in which former peasants became uprooted and ended up on the edge of urban society. The lack of a social network prevented them from finding decent and stable labor and made them vulnerable to deviant behavior like crime, alcohol abuse, prostitution, etc.

A more positive picture of the acculturation process has been put forward by authors looking at migration as a highly selective process (Lucassen, 2004; Moch, 2003; Sewell, 1985). These scholars have empirically shown that the process of social inclusion of certain groups of urban in-migrants went relatively smoothly, notably that of stayers and long-distance migrants. They have argued that urban newcomers thrived relatively well as they had more human capital in terms of education, labor market experience and skills. Stayers were often even more successful than natives, as they more often made use of opportunities economic change brought about (Sewell, 1985). As a consequence, social upward mobility occurred more often among migrants who settled permanently in a city than among the native urban population (Lucassen, 2004).

From a methodological point of view, there are major shortcomings in the existing literature on social inclusion and exclusion of urban in-migrants in the latter part of the nineteenth and the early twentieth century. In our view, studies inspired by the Chicago School of Sociology focus too much on problems migrants encountered, i.e. evidence is searched in order to proof that urban in-migrants indeed got into deep trouble upon arrival in the city. Of course, (qualitative) evidence is found that social exclusion occurred, but it remains questionable whether this picture is representative for the migrant population as a whole. Scholars who stress the selectivity of the migration process are aware of these shortcomings and therefore use a more quantitative approach towards social inclusion (Lucassen, 2004; Sewell, 1985). The results of their cross-sectional studies are however only valid for stayers as the fate of temporary migrants is hard to grasp on the basis of cross-sectional sources like marriage certificates or censuses. After all, temporary migrants hardly appear in these kinds of sources: most arrive after a census was taken and leave before a new one was carried out. Their chances of ending up in the vital registration were also considerably smaller than for stayers. Last but not least, leaving might have been a consequence of social exclusion. 


\section{A longitudinal approach to social inclusion and exclusion}

In order to reach more grounded conclusions on the fate of urban newcomers, it is necessary to also incorporate temporary migrants into the analysis. After all, stayers were only a small minority among the migrant population (Jackson, 1997. pp. 201-203; Lesger, Lucassen, \& Schrover, 2002, pp. 33-34). Incorporating temporary migrants implies working with longitudinal sources (e.g. population registers) which cover in principle all migrants, who registered themselves as residents at the city hall (like in the case of the Belgian population register) or were registered by any kind of civil servant in charge of taking account of all socio-demographic changes taking place in the city (like the Roteman in Stockholm). Another argument for applying a longitudinal approach to social inclusion and exclusion is derived from the simple fact that these are long-term processes (Hayes, Gray, \& Edwards, 2008). Consequently, (indicators of) social inclusion and exclusion are ideally studied over time on the basis of longitudinal techniques like time to event analysis.

Longitudinal techniques are clearly better suited to studying social inclusion and exclusion than cross-sectional techniques as they specifically look at individual waiting times until an event takes place. After all, the time migrants are at risk of experiencing an event differs greatly among individuals. Some migrants stay for years in a city, whereas others leave within a few months. It would, of course, be incorrect to assume that the chances of experiencing any kind of event (marriage, birth of a child, social mobility, death, etc.) are equal to a person who is one month in the city compared to a person who stays there for 20 years (Alter, 1998, pp. 13-14). Studies that use cross-sectional sources, can, at best, differentiate between persons who were at risk and persons who were not at risk of experiencing the event; the time at risk is unavoidably assumed to be equal for all individuals taken into the analysis.

Although arguments for studying social inclusion and exclusion of migrants from a longitudinal perspective are abundant, studies which indeed apply such an approach are still very scarce, both in historical and contemporary studies (Wingens, de Valk, Windzio, \& Aybek, 2011). In the case of historical studies this is largely related to source problems. In order to apply event-history analysis, high quality longitudinal data are needed. For historical populations such data are rather scarce. Within Europe only Belgium, the Netherlands and Italy established a nation-wide population register during the nineteenth century (Gutmann \& Van de Walle, 1978; Kertzer \& Hogan, 1985). Elsewhere, passive registration systems for smaller geographic entities (for example some German states) came into being. In the case of Stockholm, we have a very sophisticated and accurate source: The Roteman registration system (Geschwind \& Fogelvik, 2000).

Longitudinal source material in itself is not enough to carry out life course analyses. The data should also be stored in a way that allows us to 're-construct' (parts of) the life courses of the migrants under investigation. Databases like the Antwerp COR*-database and the Stockholm Historical Database (SHD) meet this requirement (Geschwind \& Fogelvik, 2000; Matthijs \& Moreels, 2010). These databases allow following migrants through time and space and therefore ideally permit studying the interplay between structure and agency over time. In the case of studies on social inclusion and exclusion, we should be able to study (1) elements in societies which stimulate or discourage the incorporation of newcomers, (2) characteristics of migrants which facilitate or hamper inclusion, and (3) efforts of individuals to participate in the host society. The longitudinal approach assures that changes over time (for example regarding societal openness, employment structures, attitudes or characteristics of migrants, etc.) can be incorporated into the analysis. 


\section{Access to marriage and reproductions as measures of social inclusion and exclusion}

In this article, we study which factors determined access to marriage and reproduction among different groups of migrants (with regard to geographic origin, gender and social class) in Antwerp and Stockholm in the period 1846-1926, by carrying out discrete-time event-history analyses in which the time between arrival in the city and marriage on the one hand and the time between arrival and the birth of the first child on the other hand are the dependent variables. In this way we want to get a better idea about the constraints and challenges migrants had to deal with upon arrival in Western European (port) cities. Hence, we aim to get a better insight into the chances of successful social inclusion among various groups of migrants in the two different port cities.

We view marriage and family formation as indicators of social inclusion of migrants. We assume that persons who were unable to find a partner, set up an independent household, marry and get children were socially excluded. Indeed marriage and the birth of the first child were two of the most important transitions in the life course of both natives and migrants in the Western European past, and they were closely linked to other major events, like leaving home, becoming a head of a household and inheritance transmission (Dribe, Manfredini, Oris \& Ritschard, 2010).

We define 'social inclusion' as a process which leads to a situation in which migrants are increasingly able to participate in the labor market, earn a living, have access to affordable housing, and are able to build up a sustainable social network in the host city, including intimate relationships. ${ }^{1}$ Social inclusion decreases inequalities between migrants and natives in diverse domains ranging from education, employment, consumption, housing, social security and health care services (Papillion, 2002; Sen, 2000). In this sense, social inclusion improves social cohesion in society as it reduces the gap between natives and migrants and thereby lowers the risk of tension between both social groups (Odmivar \& Richmond, 2003; Papillion, 2002). ‘... Social inclusion extends beyond bringing the "outsiders" in.... It is about closing physical, social and economic distances separating people, rather than only about eliminating boundaries or barriers between us and them (Odmivar \& Richmond, 2003: ix)'.

Social inclusion leads to the full participation of migrants in different domains of society. In this sense, social inclusion is closely related to, but not identical to assimilation, especially not if it comes to the classical use of the latter term. ${ }^{2}$ Contrary to (classic) assimilation, social inclusion is a two-way process (Papillion, 2002). Social inclusion and exclusion are also highly related to acculturation, but again acculturation places the focus on the changing behavior of the migrant, while social inclusion and exclusion also incorporate (changing) behavior of the native population.

We define social exclusion as the opposite of social inclusion. It refers to a process in which migrants are in the long run unable to find (stable) employment and to build up social ties with other city dwellers. Differently put, social exclusion prevents migrants from participation in 'basic economic and social activities' in the host city (Chakravarty \& Ambrosio, 2006). Social exclusion is related to social deprivation and poverty and is bad for social cohesion as it is likely to increase tensions between migrants and natives (Odmivar \& Richmond, 2003). Migrants who are socially excluded are isolated from mainstream society, and face all kind of social and cultural disadvantages. As such they are marginalized (Chakravarty \& Ambrosio, 2006).

We hypothesize that social inclusion and exclusion were determined by (1) the resources, skills, cultural baggage and experience individual migrants had at their disposal 
upon arrival in the city, (2) the level of societal openness they encountered, and (3) the willingness and efforts of migrants themselves to become part of mainstream society. We assert that the likelihood and timing of marriage and family formation among migrants reflect the sum of these three determinants of social inclusion.

We assume that the timing of marriage and the transition to parenthood are good indicators of the efforts it took to become socially included in a city. The more time it took after arrival to marry and start a family, the greater the constraints and challenges for migrants might have been to become socially included in the city they moved to. After all it seems very plausible that the time between arrival and marriage and family formation reflects to a large degree the time it takes for newcomers to find, amongst other things, a good job, an affordable dwelling and a suitable marriage partner. However, the fact that migrants arrived at different ages forms a complicating factor in the analysis. Migrants who arrive early on in life in the city, are more likely to have a longer time span between arrival and marriage than migrants who arrive at more advanced ages, because of legal restrictions on early marriage and unwritten rules about what is the appropriate age of marriage and the start of reproduction. We therefore have to control for age at arrival.

\section{Existing hypotheses on timing of marriage and family formation}

Many historical studies have shown that the timing and incidence of marriage and family formation varied between natives and migrants on the one hand and between different groups of migrants on the other. Most studies have focused on the fact that migrants married later and less, and that reproduction among migrants was delayed and less frequent (Kok, 2006; Lynch, 1991; Oris, 2000; Van Poppel, 1992). Figures 1 and 2 show that both in Antwerp and in Stockholm, mean ages at marriage for men and women were considerably higher among domestic and international migrants than among natives during the period of investigation.

Why nuptiality and fertility behavior among migrants differed from the native population is not self-evident. Neither is it clear what caused differences in nuptiality and family formation among different groups of migrants. According to several scholars high ages at marriage and late procreation among urban in-migrants might be caused by the fact that some groups of migrants arrived only at relatively advanced ages in the city, when many natives and other in-migrants were already married (Lynch, 1991, p. 85; Van Poppel, 1992, p. 192). Furthermore, it has been suggested that natives and migrants search for their

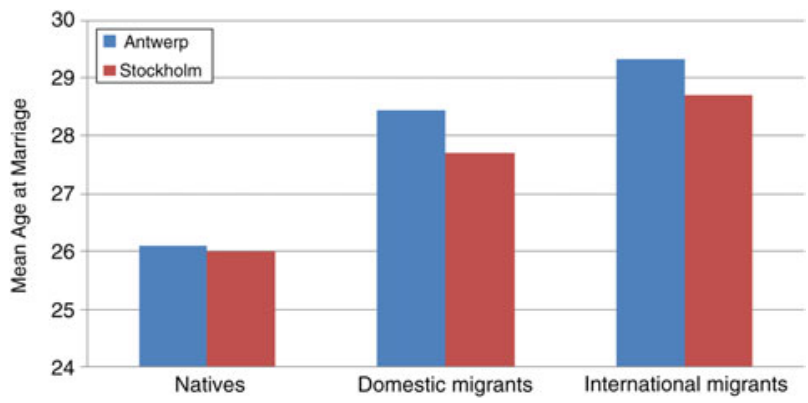

Figure 1. Mean ages at marriage among males in Antwerp and Stockholm by place of birth, 18461926*. * Antwerp: 1846-1914; Stockholm: 1878-1926. N.B. Higher order marriages are included in the data. Source: Marriage certificates 1846-1914, cor*- database, release August 2010; Stockholm Historical Database (SHD), own calculations. 


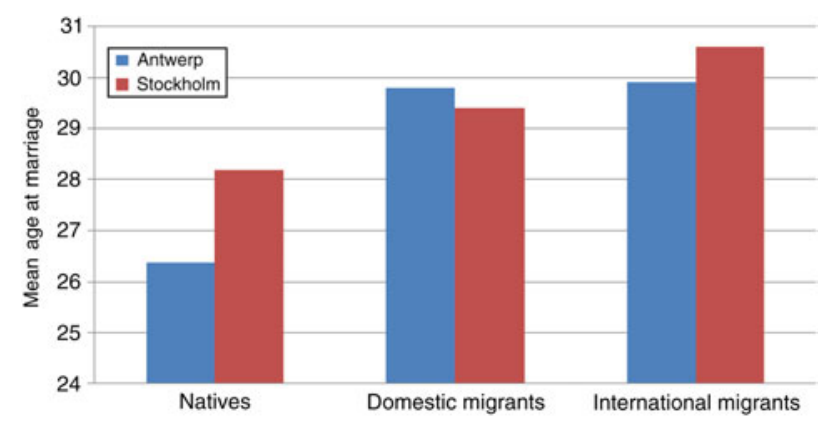

Figure 2. Mean ages at marriage among females in Antwerp and Stockholm by place of birth, 1846-1926*. N.B. Higher order marriages are included in the data. *Antwerp: 1846-1914; Stockholm: 1878-1926. Source: Marriage certificates 1846-1914, cor*- database, release August 2010; Stockholm Historical Database (SHD); own calculations.

partners in different, closed marriage markets. Distorted age and sex composition of the migrant marriage market could have seriously delayed marriage among newcomers (Kok, 2006; Lynch, 1991; Oris, 2000; Van Poppel, 1992). Other scholars have argued that the lower nuptiality among migrants is caused by a class effect. Since pre-twentieth century migrants belonged more often to lower social classes, their numeric importance may have decreased migrants' nuptiality rates, since the lowest classes often tended to marry at higher ages (Lynch, 1991, p. 85). Still others have argued that some categories of migrants drove nuptiality down as they had no intention of marrying in the city, having entered the urban environment with other targets in mind. With respect to this hypothesis we can think about servants and apprentices, who moved into the city with the intention of saving money, acquiring skills and returning back to their place of origin or moving on to another place.

However, most hypotheses on delayed marriage and family formation point at the necessity of adaptation. Migrants had first to settle at the place of destination before they were able to find a suitable marriage partner and start a family. John Hajnal pointed out that in the centuries preceding WWII, Western Europe was unique in the sense that people in this part of the world married later and less than elsewhere in the world, since newlywed couples were expected to establish a new household and it usually took a lot of time and energy to accumulate sufficient means to do so. Elsewhere in the world, fewer economic requirements for marriage were raised since newlywed couples usually moved into the household of the parents of the groom or the bride (Hajnal, 1965, 1983). According to Katherine Lynch there existed an 'exaggerated version of the European marriage pattern in the cities' (Lynch, 1991, p. 83). Lynch argues that this has, amongst other things, to do with the large presence of migrants in Western European cities. Indeed, it can be argued that becoming financially independent and finding a living accommodation - two basic economic requirements for marriage - was for migrants an even greater challenge than for natives. Finding a suitable marriage partner might also have caused more difficulties.

In nineteenth- and early twentieth-century cities, finding stable employment and a living accommodation were no self-evident events among migrants. That is already illustrated by the fact that during this period in history, Western European and North American cities were confronted with high rates of transiency (Darroch, 1981; Thernstrom, 1973). In the Dutch port city of Rotterdam, for instance, five out of six migrants left the city again within the year they had moved in (Lesger et al., 2002, pp. 33 34). In the German city of Duisburg, this figure was somewhat lower, but still immense. 
In the years $1867 / 1868$ and 1890 more than $40 \%$ of the migrants stayed less than a year in Duisburg. About half of them settled for even less than three months (Jackson, 1997, pp. 201-203). These high rates of mobility illustrate that few newcomers were able to find an urban niche. Migrants often found work only on a temporary basis and in the light of the growing housing shortage in Western and Central European cities, finding an affordable living accommodation became more and more difficult in the course of the nineteenth and early twentieth century (Lis, 1986, pp. 64-83). Who was able to stay and settle down depended upon, amongst other things, the actual situation in the local urban labor and housing markets, the human capital migrants had at their disposal and the social network they could rely on. Generally speaking, those migrants who were better educated and had more labor market skills and a larger social network were the ones who were able to compete with natives. However, of course, the local or regional opportunity structure also played a big role. In cities where an economic boom occurred more migrants were able to find a good job and integrate into the urban labor market (Lucassen, Feldman, \& Oltmer, 2006). However, during such periods of economic and demographic growth the pressure on the housing market grew as more people entered the city than new houses and apartments were constructed.

Next to finding a stable employment and an appropriate dwelling, migrants who intended to marry had to find a suitable partner. In this respect migrants seem to have been disadvantaged too. Indeed, delayed marriage and family formation among migrants might also have been a result of the fact that most of the newcomers were not very popular marriage partners among the native population. Jan De Vries (1984) has shown, for example for early nineteenth century Amsterdam, that men and women who were born in that city highly preferred partners who also originated from the Dutch capital. Partners from elsewhere in the country were less wanted among the Amsterdam-born population. Even less popular were German males and females. However, still a considerable number of Amsterdam-born brides (about 37\% in the period 1801-1806) entered their first marriages with a migrant (De Vries, 1984, p. 189). This, however, had to a large degree to do with the shortage of Amsterdam-born males. Industrialization and modernization did not terminate geographic homogamy in the marriage market. However, the degree of homogamy differed among social groups. In the Flemish cities of Ghent, Leuven and Aalst, rural migrants and migrants from the lower social classes had less chances of marrying with a native bride (Van de Putte, 2005).

That migrants were unpopular marriage partners among natives has also to do with issues related to adaptation. In order to get into an intimate relationship with a native person, a migrant had to be able to communicate in the language spoken at the place of residence. To learn a foreign language takes time. Another disadvantage in finding a marriage partner was caused by the fact that migrants often lacked a crucial social network in the city they settled down. The fact that newcomers initially did not have a large number of friends and acquaintances at the place of settlement made it more difficult to meet potential partners (Van Poppel, 1992, p. 192). Furthermore hostility against newcomers, often out of reasons related to competition in the labor and housing markets, decreased the chances for migrants to court with natives. Next, all kinds of cultural differences could form a barrier to mating. Urban dwellers had prejudices against country dwellers and vice versa. These prejudices were related to different lifestyles, dressing, dialects, and all kinds of different customs and habits, and lowered the chances of finding a partner among ruralto-urban migrants. Finally, differences in religious devotion could form a serious obstacle to finding a marriage partner. In an age in which the church still controlled the people's 
goings and doings, marrying somebody of another religion was in principle taboo (Ekamper, Van Poppel, \& Mandemakers, 2011; Van de Putte, 2003, pp. 364-365).

Apart from economic requirements and the need of finding a potential partner, there were legal barriers which could hinder migrants from marrying and starting a family. Town councils in medium-sized cities in countries such as Germany, Switzerland and the Low Countries developed all kind of laws which functioned as direct restrictions on marriage for everybody who might not be able to sustain a family on their own or enjoyed a bad reputation. ${ }^{3}$ Such restrictions were particularly directed towards minors (in the form of a minimum age for marriage), disabled and chronically diseased subjects, poor people and last but not least migrants (Head-König, 1993; Lynch, 1991, 80-81; Van den Eerenbeemt, 1977). Such Malthusian restrictions were usually intended to avoid overpopulation and the spread of poverty, which would augment the pressure on public relief within the municipality and was likewise believed to increase the threat of revolution (Knodel, 1967). In the mid-nineteenth century, direct restrictions on marriage and settlement by the local authorities continued to exist and were sometimes even temporarily reinforced. John Knodel describes the situation for Germany:

\begin{abstract}
The prospective groom, in order to gain permission from the local authorities, was required to produce evidence of having sufficient wealth or property, a secure income, or assured stable employment opportunities. A prospective wife from another community was often required to prove adequate wealth, to pay a considerable fee for permission to settle in the community, or both. The bride and groom frequently needed to provide evidence that their characters and morals were beyond reproach. Those who had a record of police conviction for fraud or theft or who had reputations as vagrants, loafers, drunkards, or even as bad housekeepers, were often denied permission. In some communities negligence in church or Sunday school attendance was a bar to marriage (Knodel, 1967, pp. 279-280).
\end{abstract}

For migrants it was more difficult to deal with the legal requirements of marriage at the time, as the application for and delivery of legal documents, like a birth certificate or a death certificate of a parent, had to take place at their place of origin (Schumacher, Ryckzkowska, \& Perroux, 2007). This meant in practice traveling or having sent forward documents from the home municipality. At best, a retardation of the legal procedure was the outcome. In practice, as Schumacher et al. (2007) have pointed out, such practical legal barriers opened the way to consensual unions and unwed motherhood.

However, towards the end of the nineteenth century and the early twentieth century, restrictions on marriage and residence were repealed legally and accordingly nuptiality started to increase (Knodel, 1967). This must have especially increased the chances of migrants to settle down, marry and start a family.

\title{
5. Two different types of growing port cities: Antwerp and Stockholm
}

Antwerp and Stockholm were two port-cities which experienced considerable population growth in the course of the nineteenth century as a result of declining mortality and rising urban in-migration (see Figure 3). Antwerp's population (including its suburbs Berchem, Borgerhout, Deurne, Hoboken, Merksem and Wilrijk) grew from 108,737 inhabitants in 1846 to 504,711 in 1930. As a result, Antwerp turned into the fastest growing city of Belgium and became the country's most populous city in the latter half of the nineteenth century. Stockholm's total population developed in the same period of time from 88,400 to 502,203 inhabitants. Around the middle of the nineteenth century Antwerp hosted about 20,000 inhabitants more than Stockholm. Around 1930 the cities had a comparable population size, as Stockholm's population had grown at a somewhat higher rate than 
Antwerp. Stockholm experienced a population boom from about 1910 onwards. At that time population growth in Antwerp, which was previously somewhat higher than in the Swedish capital, had slowed down considerably.

An important difference in the cities' population composition is related to sex. Stockholm had a female surplus during the period of observation, especially for the age categories above age 18. In Antwerp, the sex composition of the population was more balanced. Differences in sex composition between Antwerp and Stockholm were probably the result of opposite migratory patterns, which most likely reflect differences in the labor market. Stockholm's diversified labor market offered many jobs for females. In Antwerp, by contrast, fewer jobs for females were available, as the city's economy was dominated by port-activities, which demanded physical strength (Winter, 2009).

Both cities attracted massive numbers of domestic and international migrants during the period of observation. However, migration was not a one-way movement towards the city. Many migrants moved back and forth between the city and its hinterland (Winter, 2009). That explains why levels of out-migration were also large. In the case of Antwerp, temporary migration was even a more important phenomenon, as hundreds of thousands of European emigrants embarked in Antwerp for the New World. Antwerp's Red Starline connection with North America expanded quickly between the 1870 and 1920 and handled even more passengers than the Holland America Line and the Compagnie Générale Transatlatlantique (Hoste \& Loyen, 2002, p. 193).

In the long run net-migration contributed considerably to total population growth (both in Antwerp and Stockholm), as the number of in-migrants exceeded the number of outmigrants. Most of the migrants originated still from the direct (rural) hinterland, but the average distance to the places of birth increased over time (Moch, 2003; Winter, 2009). Also, the absolute numbers of international migrants grew further and further. Most international migrants originated from the neighboring countries. In the case of Antwerp, many foreign newcomers were born in the Netherlands, Germany and France. Moreover, considerable numbers of international migrants originated from England, AustriaHungary and the Russian Empire. In 1900, 32,515 international migrants lived in Antwerp. They made up about $12 \%$ of the total population (Saerens, 2000). Stockholm received first of all migrants from the other Nordic countries, especially from Finland.

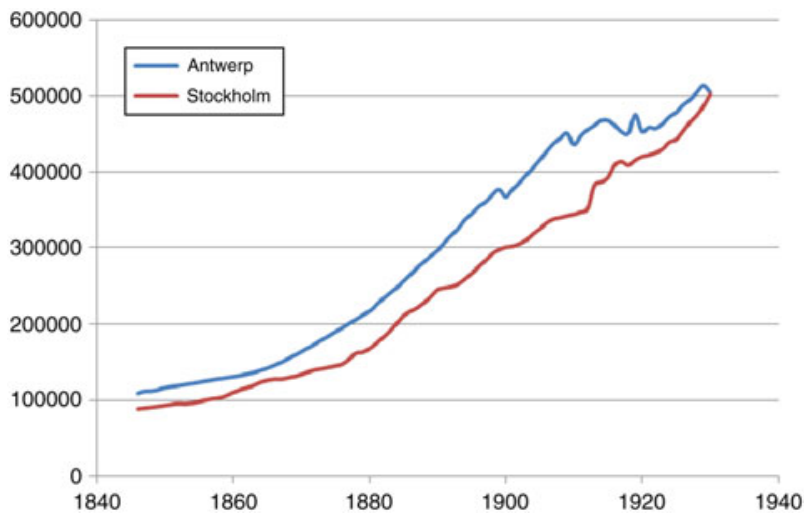

Figure 3. Total population in Antwerp ${ }^{7}$ and Stockholm, 1846-1930. Source: Historische databank van Lokale Statistieken LOKSTAT; statistical yearbooks of Stockholm. 
Moreover, considerable numbers of Russians and Germans lived in the Swedish capital. In total, Stockholm hosted 5847 international migrants in 1900, which was about $2 \%$ of the total population (Statistiska Centralbyrån, 1900, p. 95). From this point of view Antwerp was a more international city at that time.

In terms of economic development, Antwerp and Stockholm were quite different from each other. In the course of the nineteenth century, Antwerp turned into a world port (Greefs, 2008; Lis, 1986; Winter, 2009). As such, the city's economy was dominated by commerce and shipping. Although industry was growing towards the end of the nineteenth and the early twentieth century, Antwerp did not turn into a real industrial city. Port labor offered by far the largest employment opportunities and industry in the form of shipbuilding, ship-reparation, food, and small-scale metal and wood industry, remained only of local and regional importance. ${ }^{4}$ According to De Brabander (1986, p. 309) Antwerp's industry was so tiny that it could not even stimulate Antwerp's port activities. That does not, however, mean that Antwerp did not profit from industrialization. Indirectly it certainly did, as Belgian, German (especially in the Ruhr area) and French industrialization gave a boost to trade. Antwerp's excellent railway connections made sure that ever larger quantities of cargo were shipped in its port. In this way Antwerp became a strong competitor of Rotterdam (De Goey, 2004).

Stockholm was also a port city, but although the port offered important employment opportunities, it did certainly not dominate the city's economy, as was the case in Antwerp. ${ }^{5}$ Raw materials essential for Stockholm's industrialization and growth arrived to the port from around Sweden. The capital's industrial growth was indeed primarily based on natural resources from other parts of the country (Ahlenius \& Kempe, 1909, p. 874; Högberg, 1981, pp. 91-95, 98-99, 104-115, 130-133). As such, one can argue that Stockholm's port served the city's industrial development.

That Stockholm was indeed turning into a real industrial hot spot is illustrated by the following figures. Between 1878 and 1926, the number of industries grew from 329 to 1172 and the number of industrial workers increased from 8093 to 42,424 . Stockholm's capital position facilitated manifold industrialization; industrialists were able to utilise foreign contacts through scientific and cultural institutions, which made technical innovations arrive early. The engineering industry, the food and stimulus industry as well as the typically capital-based graphic industry played major roles in the transformation (Högberg, 1981, pp. 91-95, 98-99, 104-115; Statistiska Centralbyrån, 1878-1912; Statistiska Centralbyrån, 1914-1928).

Another big difference between Stockholm and Antwerp is related to the fact that Stockholm functioned as a national capital, while Antwerp was only a county seat. As a capital, Stockholm offered plenty of government related jobs, which were absent in Antwerp.

Because of more stability and more diversity in the labor market, we expect that migrants in Stockholm had a higher incidence of getting married and becoming a parent. Moreover we expect that these life time events occurred earlier on in the life course among migrants in the Swedish capital. After all, unemployment rates tend to be lower in areas with a more diversified job offer (Neumann \& Topel, 1991), while at the same time the existence of employment in industry and government related jobs might have increased income stability. These two positive aspects of Stockholm's labor market might have made it easier for individual migrants to meet the economic requirements for marriage. On the other hand, Antwerp hosted a much larger number of international migrants. This might have been the result of its different geographic location, but might also reflect a higher degree of societal openness. Moreover the fact that Antwerp's port revival was first of all the success of external forces and foreigners (Greefs, 2008), might have created a climate in which 
newcomers were more welcomed, both in the labor and in the marriage market. Finally, because of the skewed sex ratio in Stockholm, which increased competition in the marriage market (due to an excess of females), we expect that female migrants in Stockholm had somewhat lower odds for getting married and starting reproduction than male migrants.

\section{Data and methods}

The data for the city of Antwerp are drawn from the COR*-database (Matthijs \& Moreels, 2010; Van Baelen, 2007). Based on the population registers and the vital registration of births, marriages and deaths of the district of Antwerp, this letter sample covers the period 1846-1922 and contains longitudinal data on about 30,000 individuals whose surname began with the letters C-O-R as well as their resident relatives. The database contains individual information on demographic events such as birth, marriage, death and migration as well as information that allows us to define individual socio-economic profiles. For the purpose of this study we first identified all domestic and international migrants solely on the basis of their place of birth, since other information such as nationality is usually not given in the registers. We selected all individuals who were neither born in the city of Antwerp nor in one of the suburbs Berchem, Borgerhout, Deurne, Hoboken, Merksem or Wilrijk, but who lived in this larger urban Antwerp area at a certain stage in their life course. Doing so, we found about 10,000 migrants, among whom about 4000 were unmarried upon their first entry in the registers.

While the registration of births, marriages and deaths is assumed to be correctly reported, dates of arrival and departure are often missing. Although both in- and outmigration were events of which registration was compulsory, they were often not reported to the local government offices. In order to include individuals without known date of arrival and to estimate the true exposure time of migrants whose date of departure is missing, we imputed dates of in- and out-migration on the basis of individuals' presence history in the population registers. Registers were opened in 1846, 1856, 1866, 1876, 1880, 1890,1900 and in 1910. When a register was opened, all individuals present at that time were recorded and incoming migrants successively added during the covered period. Consequently, an individual whose first presence is found in the 1866 register must have arrived between 1866 and 1876, whereas a migrant whose last presence is recorded in the 1890 register must have left between 1890 and 1900. For an individual i whose date of arrival is missing, we defined the imputed year of in-migration I as a random number within a range of possible years defined as the difference of the minimum between the opening year of the following register $\mathrm{R}_{\mathrm{t}+1}$, a potentially recorded year of departure $\mathrm{O}$ and a potentially given year of death $\mathrm{D}$ on the one hand and the maximum between the opening year of the register of first presence $\mathrm{R}_{\mathrm{t}}$ and individual i's birth year $\mathrm{B}$ on the other hand:

$$
\mathrm{I}_{\mathrm{i}}=\mathrm{R}_{\mathrm{t}, \mathrm{i}}+\operatorname{random}\left(\operatorname{range}_{\mathrm{i}}\right), \quad \text { with range } \mathrm{i}_{\mathrm{i}}=\min \left(\mathrm{R}_{\mathrm{t}+1, \mathrm{i}}, \mathrm{O}_{\mathrm{i}}, \mathrm{D}_{\mathrm{i}}\right)-\max \left(\mathrm{R}_{\mathrm{t}, \mathrm{i}}, \mathrm{B}_{\mathrm{i}}\right)
$$

Records of our events of interest, i.e. marriages and first births, have not been used to define the ranges of possible years of in-migration, as this may have induced selection biases in our imputations. Similarly, we defined the imputed year of out-migration $\mathrm{O}$ as a random number within a range of possible years defined as the difference of the opening year of the following register $R_{t+1}$ and the maximum between the opening year of the register of last presence $R_{t}$ and the individual's year of arrival I:

$$
\mathrm{I}_{\mathrm{i}}=\mathrm{R}_{\mathrm{t}, \mathrm{i}}+\operatorname{random}\left(\operatorname{range}_{\mathrm{i}}\right), \quad \text { with } \operatorname{range}_{\mathrm{i}}=\mathrm{R}_{\mathrm{t}+1, \mathrm{i}}-\max \left(\mathrm{R}_{\mathrm{t}, \mathrm{i}}, \mathrm{I}_{\mathrm{i}}\right)
$$


For individuals who died during the period covered by the register in which their last record could be found, no year of departure has been imputed. Again, reported dates of marriage and first birth have not been used to determine the range of possible years of out-migration, as this would have meant to define the exposure time with information on the dependent variables. For the sake of simplicity, only continuous presence histories have been taken into account, i.e. only one year of out-migration has been imputed per individual, even if part of the population which left came back to Antwerp in later years.

The data we used for the city of Stockholm have been retrieved from the Stockholm Historical Database (SHD) (Geschwind \& Fogelvik, 2000). This database covers the period 1878-1926 and contains detailed and reliable information on all inhabitants in 23 out of 36 wards (rotar) in five coherent districts of the city. SHD is based on the Roteman registration system and consists of yearly censuses with detailed information at the individual level. Unlike COR*-, SHD is not a population sample and covers only parts of Stockholm city. For the purpose of this study we used two retrievals of the SHD. The first retrieval refers to international migrants and contains all individuals born abroad who migrated directly from abroad and who were at least 16 years of age by arrival. The second retrieval refers to domestic migrants who have been selected out of a $20 \%$ sample of the total database. When selecting the unmarried population we end up with about 6500 international and 63,500 domestic migrants.

The Roteman - a municipal registrar - continuously updated the information on the recorded individuals. Events, in particular in-migration, marriage, birth of first child, outmigration and death, should therefore be reliably reported. Nevertheless, in a small number of cases the migration history before arrival is unknown, and in some cases, no date of in-migration has been reported.

In both contexts, our analyses of times to marriage and first observed birth since immigration are restricted to the unmarried population aged 18 to 50. Individuals who immigrated as children enter the risk set only when reaching age 18 . The total exposure time is therefore 32 years. After applying our selection criteria regarding civil status and age, we remain with about 2000 migrants in greater Antwerp among whom the year of arrival has been imputed in $25 \%$ of all cases and the year of departure in about $70 \%$ of all cases. Our Stockholm sample consists of about 52,000 domestic and international migrants.

In order to study the occurrence and the timing of marriage and first birth among these migrants we conducted a discrete-time survival analysis. In a first step, we analyzed survival times until marriage and first observed birth using the life table estimator and plotted survival curves. In a second step we ran discrete-time logit models predicting the hazard rates of getting married and of having a first child as a function of time since immigration, age at immigration, historical time period, gender, region of birth, place of birth (urban or rural) social class and civil status (the latter for the models of first birth only). Time since immigration, historical time period, and civil status (unmarried vs. married) have been included as time varying variables. Our measure of social class is based on HISCLASS (Van Leeuwen \& Maas, 2011): upper classes comprise HISCLASS codes 1 to 3, middle classes codes 4 to 7 and lower classes codes 8 to 12 . To control for unobserved heterogeneity, we specified normally distributed random intercepts in all models.

\section{Results}

Figure 4 shows the survival times until marriage and first observed birth among unmarried migrants in Antwerp between 1846 and 1922. The overall hazard of getting married increases during the first seven years since arrival and declines thereafter which means that 
the hazard function is inversely U-shaped. Men and women do not differ substantially from each other in their probability of getting married. Among both sexes, about $25 \%$ marry within the first five years after arrival, and after 10 years of residence in Antwerp, about $40 \%$ have found a spouse.

The time dependency of the hazard of having a first birth is also best summarized as an inversely U-shaped curve. The rate of observing a birth increases during the first eight to nine years since arrival and decreases afterwards, although an upheaval of the rate can be observed after 15 years. At any time, the proportion of immigrants whose access to fertility is lower than the proportion married. Within the first five years of residence in Antwerp, about $10 \%$ of the unmarried immigrant population has a first birth, while after 10 years about $30 \%$ have had access to reproduction. No substantial difference between men and women can be observed, although among women survival times are slightly shorter.

Table 1 shows the results of two random-intercept discrete-time logit models of time to marriage and time to first birth among migrants in Antwerp. Except for the fixed and random parts of the intercepts, the coefficients have been exponentiated and should therefore be interpreted as hazard (odds) ratios. The number of years since arrival has been included in both linear and squared forms to model the inversely U-shaped function of the baseline hazard.

The model of time to marriage indicates substantial associations between access to marriage on the one hand and age at immigration, historical time period, region of birth and completeness of migration history on the other hand. In contrast, gender and social class do not seem to be related with time to marriage. Among migrants who arrived in Antwerp before the age of 35 years, no difference in access to marriage can be observed. However, individuals who immigrated after that age were clearly less likely to marry than younger migrants. The model also shows a steady increase over historical time in migrants' hazard of getting married. After 1906, for example, migrants were more than three times as likely to marry in town as before 1890. This is a clear sign that the European marriage pattern of late marriages and large proportions of bachelors and spinsters was gradually disappearing. Migrants might have especially profited from this situation, as they previously had had less chances of getting married. Equally, the increased risk of a
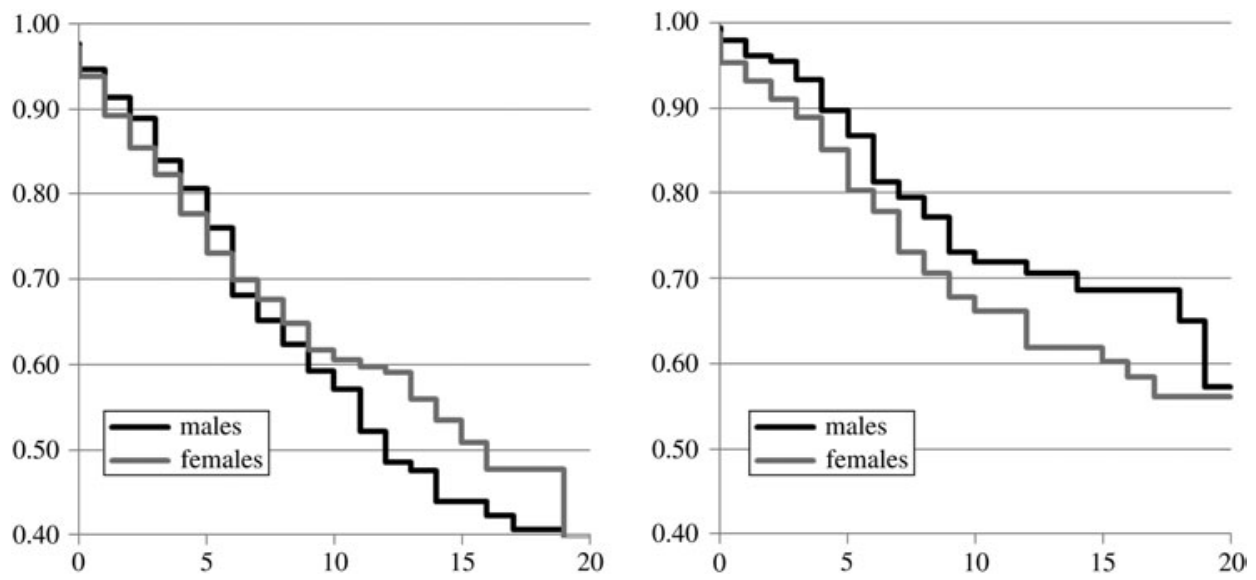

Figure 4. Time to marriage and first observed birth in Antwerp among unmarried migrants. Lifetable survival curves. 
Table 1. Discrete-time survival models of marriage and first observed birth among unmarried migrants in Antwerp.

\begin{tabular}{|c|c|c|c|c|}
\hline & \multicolumn{2}{|c|}{ Time to marriage } & \multicolumn{2}{|c|}{ Time to first birth } \\
\hline & OR & $p$-value & OR & $p$-value \\
\hline Years since immigration & 1.156 & 0.000 & 1.324 & 0.004 \\
\hline Years squared & 0.992 & 0.000 & 0.985 & 0.001 \\
\hline \multicolumn{5}{|l|}{ Age at immigration } \\
\hline$<18$ & 1 & ref & 1 & ref \\
\hline $19-24$ & 1.172 & 0.255 & 0.884 & 0.628 \\
\hline $25-34$ & 0.905 & 0.525 & 0.429 & 0.005 \\
\hline $35+$ & 0.619 & 0.026 & 0.067 & 0.000 \\
\hline \multicolumn{5}{|l|}{ Historical period } \\
\hline $1846-1869$ & 0.258 & 0.000 & 0.260 & 0.000 \\
\hline $1870-1889$ & 1 & ref & 1 & ref \\
\hline 1890-1905 & 2.161 & 0.000 & 0.745 & 0.228 \\
\hline 1906-1922 & 3.593 & 0.000 & 0.334 & 0.000 \\
\hline \multicolumn{5}{|l|}{ Gender } \\
\hline Male & 1 & ref & 1 & ref \\
\hline Female & 0.946 & 0.627 & 1.307 & 0.254 \\
\hline \multicolumn{5}{|l|}{ Region of birth } \\
\hline Province of Antwerp & 1.110 & 0.410 & 1.568 & 0.083 \\
\hline Flanders & 1 & ref & 1 & ref \\
\hline Brussels area & 1.455 & 0.107 & 0.468 & 0.187 \\
\hline Wallonia & 1.028 & 0.900 & 0.663 & 0.333 \\
\hline Outside Belgium & 0.623 & 0.008 & 0.614 & 0.158 \\
\hline Unknown & 0.484 & 0.063 & 0.194 & 0.171 \\
\hline \multicolumn{5}{|l|}{ Place of birth } \\
\hline Urban & 0.874 & 0.286 & 0.552 & 0.023 \\
\hline Rural & 1 & & 1 & ref \\
\hline unknown & 0.759 & 0.576 & 0.816 & 0.871 \\
\hline \multicolumn{5}{|l|}{ Social class } \\
\hline Upper & 0.914 & 0.747 & 0.646 & 0.554 \\
\hline Middle & 0.830 & 0.232 & 0.571 & 0.094 \\
\hline Lower & 1 & ref & 1 & ref \\
\hline Unknown & 1.132 & 0.357 & 2.386 & 0.003 \\
\hline Year of immigration not known & 0.533 & 0.000 & 0.297 & 0.004 \\
\hline Year of outmigration not known & 1.579 & 0.000 & 1.065 & 0.790 \\
\hline Married & & & 21.23 & 0.000 \\
\hline Intercept & -4.218 & 0.000 & -4.875 & 0.000 \\
\hline random intercept (stdev) & 0.003 & 0.496 & 1.722 & 0.000 \\
\hline Observed person-years & 10508 & & 10062 & \\
\hline Observed individuals & 2010 & & 2038 & \\
\hline Observed events & 374 & & 213 & \\
\hline
\end{tabular}

first marriage over time might reflect growing societal openness or a change over time in peoples' motivation to migrate.

It is not surprising to find that international migrants were only half as likely to find a spouse as Belgians, whereas the absence of any differences within the group of domestic migrants is rather surprising. Furthermore, we believe that the negative impact of a lacking year of arrival in the population register on the hazard of marriage, as well as the positive influence of a missing date of outmigration on the likelihood of getting married, are due to unobserved characteristics of these subpopulations rather than to our imputation method. 
The model of time to first birth shows significant associations between the access to reproduction on the one hand and age at immigration, historical time period, region and place of birth, social class and marriage on the other hand. Again, no significant difference can be found between men and women. The regression coefficients report a sharp decrease in the propensity of experiencing a first birth among migrants who arrived in Antwerp after the age of 25 years. Individuals who immigrated after the age of 35 years were even 15 times less likely to have a first birth in Antwerp than individuals who arrived before age 25. Contrary to marriage, the access to reproduction did not increase over time in Antwerp. The association between calendar time and the hazard of having a first birth we found is not monotonic. Immigrants were most likely to have a first child between 1870 and 1905, whilst the hazard was lower before and after that period. The association between region of birth and access to reproduction is due to three distinct groups in terms of fertility behavior: short-distance migrants born in the province of Antwerp, Flemings and international immigrants. Individuals born in the province of Antwerp were most likely to have a child in town, followed by all other Flemings and by foreign nationals who were least likely to have a child in Antwerp. All things being equal, migrants born in urban places were at lower odds of experiencing first birth in Antwerp. Migrants of the middle and upper social classes were less likely to have children than laborers, although these differences did not turn out to be statistically significant. Migrants of unknown social class, however, were subject to a clearly increased hazard of having a first birth in town. Finally, the association between marital status and access to reproduction is as expected very important. After marriage, the hazard immediately jumps to a rate 20 times as high as before marriage. In this model, the random intercept is large and significant, which means that there is a source of inter-individual heterogeneity we do not observe.

Figure 5 shows the survival times until marriage and first birth among the unmarried immigrant population in Stockholm between 1878 and 1927. Due to the high numbers of observed individuals and events, the empirical hazard functions follow almost perfectly inversely U-shaped curves. The hazard of getting married is highest in the fifth year after arrival and decreases thereafter, whilst the hazard of having a first child in town reaches its maximum after about 10 years of residence. In Stockholm, men and women differ significantly between each other with respect to time to marriage, men getting married at a higher rate than women. Among the latter about $30 \%$ marry within the first 10 years after arrival and about $40 \%$ do so within the first 15 years, whereas among the former the proportions rise to $40 \%$ and $50 \%$ respectively. No significant gender differences, by contrast, can be observed with respect to time to first birth. The comparison with Antwerp shows that Stockholm migrants married at a lower rate and also had less frequently a first child in their new home town.

Table 2 shows the results of two discrete-time survival models of time to marriage and time to first observed birth among unmarried migrants in Stockholm. Both models contain a random intercept that turned out to be highly significant, which means that part of the between-individual heterogeneity cannot be explained by the independent variables we include in our models. Thanks to the specification of random intercepts, the estimation of the regression coefficients should be unbiased. As in the models for the Antwerp data, we included time since immigration in linear and squared form to model the inversely Ushaped baseline hazard.

The model predicting the hazard of getting married gives evidence for substantial associations between access to and rhythm of marriage on the one hand and age at immigration, historical time period, gender, region and place of birth and social class on 

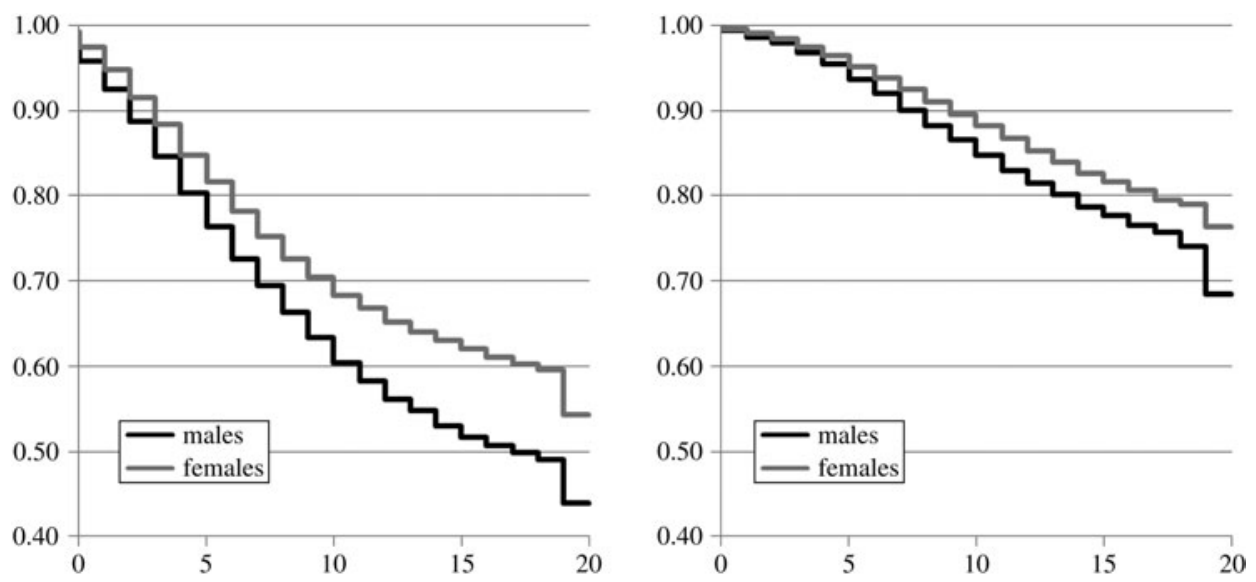

Figure 5. Time to marriage and first observed birth in Stockholm among unmarried migrants. Lifetable survival curves.

the other hand. Interestingly, the hazard of getting married increases with age at immigration among migrants who arrived before the age of 35 years. Individuals who immigrated when 25 to 34 years old got married twice as fast as those who arrived before the age of 18 years. This result differs considerably from that found in the Antwerp data and may be due to differences in common age at marriage. The lower rate of marriage found in the female population may in turn be explained by the unbalanced sex ratio. In Stockholm, we cannot observe the steady increase in the hazard of getting married we found in the Antwerp model. On the contrary, the hazard declined by $20 \%$ between the first and the second time period considered. Our results further show that short-distance migrants born in the Stockholm area married in higher proportions than domestic and international immigrants, with the exception of Russians who married clearly faster and also in higher proportions than all other groups. Migrants whose place of birth could not be classified as urban or rural were at lower odds of concluding first marriage in Stockholm. Finally the model also shows that upper and middle class immigrants married at a faster rate than lower class migrants.

The model of time to first birth indicates significant associations between access to reproduction on the one hand and age at immigration, historical time period, region and place of birth and civil status on the other hand. Gender does not seem to be related with time to first birth, and social class only to a limited extent. As expected, the hazard of having a first child in town is much lower among migrants who arrived after the age of 35 years. As in Antwerp, the hazard also declines in Stockholm during the last time period (1906-1927), but to a much lower extent than in the Flemish city. The model gives evidence of an interesting opposition with respect to first birth between domestic migrants on the one hand and international migrants on the other hand. The former who did not differ significantly between each other in terms of time to first birth were clearly less likely to have a first birth in the city of Stockholm than the latter. Among international migrants, Russians were by far most likely to have a first child in town and also were subject to clearly shorter waiting times. This opposition between domestic and international migrants in terms of reproduction may indicate differences in the motivation to migrate. As to the particular behavior of Russian immigrants - they were most likely to marry- it may be related to specific community 
Table 2. Discrete-time survival models of marriage and first observed birth among unmarried migrants in Stockholm.

\begin{tabular}{|c|c|c|c|c|}
\hline & \multicolumn{2}{|c|}{ Time to marriage } & \multicolumn{2}{|c|}{ Time to first birth } \\
\hline & OR & $p$-value & OR & $p$-value \\
\hline Years since immigration & 1.479 & 0.000 & 1.110 & 0.000 \\
\hline Years squared & 0.983 & 0.000 & 0.994 & 0.000 \\
\hline \multicolumn{5}{|l|}{ Age at immigration } \\
\hline$<18$ & 1 & ref & 1 & ref \\
\hline $19-24$ & 1.527 & 0.000 & 1.158 & 0.044 \\
\hline $25-34$ & 2.064 & 0.000 & 0.963 & 0.646 \\
\hline $35+$ & 0.772 & 0.008 & 0.376 & 0.000 \\
\hline \multicolumn{5}{|l|}{ Historical period } \\
\hline $1878-1889$ & 1.199 & 0.000 & 1.016 & 0.831 \\
\hline 1890-1905 & 1 & & 1 & ref \\
\hline $1906-1927$ & 0.981 & 0.577 & 0.683 & 0.000 \\
\hline \multicolumn{5}{|l|}{ Gender } \\
\hline Male & 1 & ref & 1 & ref \\
\hline Female & 0.698 & 0.000 & 0.924 & 0.146 \\
\hline \multicolumn{5}{|l|}{ Region of birth } \\
\hline Stockholm county & 1 & ref & 1 & ref \\
\hline East central Sweden & 0.858 & 0.011 & 0.911 & 0.338 \\
\hline Southern Sweden & 0.706 & 0.000 & 0.911 & 0.326 \\
\hline Gothenburg & 0.631 & 0.001 & 0.793 & 0.384 \\
\hline Northwest central Sweden & 0.687 & 0.000 & 0.966 & 0.735 \\
\hline Northern Sweden & 0.567 & 0.000 & 0.775 & 0.080 \\
\hline unknown domestic & 1.010 & 0.962 & 1.213 & 0.575 \\
\hline Finland & 0.699 & 0.000 & 7.083 & 0.000 \\
\hline Norway & 0.969 & 0.829 & 9.459 & 0.000 \\
\hline Russia & 2.600 & 0.000 & 20.994 & 0.000 \\
\hline Germany & 0.960 & 0.708 & 7.065 & 0.000 \\
\hline other international & 0.699 & 0.014 & 4.118 & 0.000 \\
\hline \multicolumn{5}{|l|}{ Place of birth } \\
\hline Urban & 0.922 & 0.041 & 0.882 & 0.045 \\
\hline Rural & 1 & ref & 1 & ref \\
\hline Unknown & 0.452 & 0.000 & 0.475 & 0.000 \\
\hline \multicolumn{5}{|l|}{ Social class } \\
\hline Upper & 1.410 & 0.001 & 0.762 & 0.133 \\
\hline Middle & 1.130 & 0.008 & 0.827 & 0.009 \\
\hline Lower & 1 & ref & 1 & ref \\
\hline Unknown & 0.959 & 0.332 & 0.977 & 0.732 \\
\hline Married & & & 62.06 & 0.000 \\
\hline Intercept & -5.340 & 0.000 & -7.431 & 0.000 \\
\hline Random intercept & 1.589 & 0.000 & 1.340 & 0.000 \\
\hline Observed person-years & 292408 & & 335732 & \\
\hline Observed individuals & 51897 & & 51786 & \\
\hline Observed events & 7820 & & 2941 & \\
\hline
\end{tabular}

effects, like religion. After all, the Russian-born migrants were to a large extent Jewish. Again, migrants with a non-classifiable place of birth along the urban/rural scale were less likely to experience first birth in Stockholm. Finally the model shows as expected a very marked association between marital status and reproduction. As in Antwerp the hazard of observing a first birth jumps to much higher rates after marriage. 


\section{Discussion and conclusion}

In this paper we have used the timing and incidence of first marriages and first births as indicators of the process of social inclusion of different groups of migrants in Antwerp and Stockholm in the late nineteenth and early twentieth centuries. We have argued that the timing and incidence of these two lifetime events are good indicators of the time it takes to get socially included in urban societies of that time. Our main goal has been to detect individual and contextual factors which could have facilitated or hampered migrants' social inclusion.

Our study is innovative in the sense that we apply a longitudinal instead of a crosssectional approach to social inclusion. This is an advantage as social inclusion in itself is a process which may last for years. The process should therefore ideally be studied on the basis of longitudinal techniques, like event history analysis, which specifically focus on individual waiting times until an event of social inclusion takes place. Cross-sectional approaches do not take into account that the time at risk among migrants greatly differed as some migrants stayed only for a few weeks or months in the city, while others stayed for years. It is wrong to assume that both categories of migrants had the same risk of experiencing events of social inclusion. Our longitudinal databases allow us to include both movers and stayers, which is often impossible on the basis of cross-sectional approaches, as the largest part of the movers were not covered by the sources. They arrived after a census was taken and left before a new-one was carried out. Their odds of ending up in the vital registration were equally considerably lower.

One of the findings in this study points to the fact that migrants who originated from within the direct vicinity of Stockholm had better chances of social inclusion. This can be explained by the fact that those migrants might have differed less from the native Stockholm population in terms of cultural traits such as language/dialect, identity, values and all kinds of habits and customs. Moreover, migrants who moved over smaller distances could more likely rely on a social network upon arrival in the city and they also could more easily rely on assistance from family and friends of their place of birth. Furthermore, migrants who originated from the city's hinterland might already have had a better picture of what life was like in the city they moved to, since they were more likely to have visited the city before. These results are in contrast with studies (Lucassen, 2005; Lucassen et al., 2006) which stress that the social inclusion of long distance migrants was easier as they had more human capital at their disposal, due to selection effects in the migration process.

For Antwerp, we did not find any significant differences for region of birth within Belgium, which in the first instance suggests that region of birth within Belgium did not affect one's chances regarding social inclusion in Antwerp. Especially striking is the fact that we did not find any significant differences for the French speaking Walloon population, but this might be related to a relatively small $\mathrm{n}$ for this particular subpopulation.

In Antwerp as well as in Stockholm, international migrants had more difficulties in becoming socially included than domestic migrants. Cultural barriers in the form of language problems might have hindered them from finding a native partner, while the number of potential partners of their own nationality was limited. For certain groups, however, this was not the case. This study indicates, for example, that a high degree of social inclusion took place among Russian born migrants, who benefited from the large Russian-Jewish community in the Swedish capital. This result shows the importance of the size and organization of individual migrant communities for the social inclusion of 
newcomers. In this sense, settled migrants function as 'beachheads' for newcomers (Böcker, 1994). This is especially true in the case of chain or network migration. Already settled migrants reduced not only the costs and risks of moving to an unknown destination, they also facilitated the settlement process by offering newcomers temporary shelter, by assisting them in finding employment, affordable housing, a marriage partner, etc. Settled migrants can also act as interpreters and they can help in arranging residence papers (De Haas, 2003).

As for age at arrival, migrants who entered Antwerp at a young age experienced higher chances of social inclusion. This result should not surprise us, since migrants who arrive young go through all kinds of socialization and adaptation processes (for example in school) at the place of destination, through which they eventually differed less from the native population than migrants who lived a larger part of their life elsewhere and arrived only at more advanced ages. In the case of Stockholm, the situation is somewhat different since migrants who arrived between ages 25 and 34 enjoyed higher chances of getting married than migrants who arrived at younger ages. This might be related to different social norms regarding marriage and the appropriate age of entering matrimony. After all, in Stockholm, consensual unions, either temporary or permanent, were more socially accepted than in Antwerp (Matovic, 1986).

Regarding social class, no significant results were found for Antwerp, except that migrants with unknown social classes were at an increased risk of receiving a first birth. In the case of Stockholm, the middle and especially the upper class were at an increased risk of getting married. We could therefore conclude that the social inclusion of migrants of the middle and higher classes went more smoothly. Since social class is highly related with education, social, cultural and economic capital, we can assume that these migrants integrated more easily in Stockholm as they had more resources available. However, we should be careful with our interpretation, since consensual unions (the so-called Stockholm marriage) were widely accepted in the Swedish capital, especially among the lower classes (Matovic, 1986). Moreover, upper and middle class migrants in Stockholm had lower odds of receiving a first birth. However, we believe that time until marriage is still a better indicator of the social inclusion process than time to first birth. Especially towards the end of the period of investigation, when fertility had decreased considerably, the timing of the first birth might say more about family planning than about getting access to reproduction. Moreover, we know that families from the upper and middle class were pioneers in birth control practices (Matthijs, 2001, pp. 120-122).

In the case of Antwerp, no significant sex-differences were found, whereas in Stockholm women had somewhat lower chances of experiencing a first birth and considerably smaller chances of getting married. This is most likely related to the female surplus in the Swedish capital. As a consequence, female migrants in Stockholm experienced more competition in the labor and marriage market, which complicated their social inclusion. This result is clearly in line with our hypothesis.

On the basis of our results, it looks like social inclusion was somewhat easier in Antwerp, since the survival curves showed that in the Belgian port city migrants married at a higher rate and had more often access to reproduction. This is at first glimpse surprising since Stockholm had a much more diversified labor market, which we expected to have had a positive effect on the chances for newcomers to find a good job and settle. The largest part of Antwerp's migrants ended up, by contrast, in port-related labor, which was rather insecure as employment in this specific sector of the economy was mostly of temporary nature. However, it is true that Antwerp's port revival and thereby the city's economic success was largely accomplished by migrants, since the city's native elite had 
been involved in textile industry, which had largely vanished in the early nineteenth century (Greefs, 2008; Winter, 2009). This might have created a climate in which inmigration was more appreciated. Moreover, the fact that Antwerp was flooded by national and international migrants, that the city was a gateway between Europe and the New World and that the city's economic prosperity was highly dependent on international commerce, might have created a situation in which migrants were more easily welcomed than in Stockholm, where industrialization was rather a domestic success.

Urban in-migrants in Antwerp thus had better chances of getting socially included, and their chances grew even larger over time. In Stockholm, by contrast, chances for social inclusion were smaller and they got smaller over time. We could assume therefore that Antwerp's society was getting more open, while in Stockholm an opposite motion was going on. Following this reasoning, the Belgian port city increasingly welcomed newcomers, while the Swedish capital was more and more closing its gates for outsiders. This divergent motion might also be linked to differences in demographic growth. Since Stockholm kept on growing larger as a consequence of natural population growth and sustained urban in-migration, it might have become more difficult to find an urban niche for newcomers. In Antwerp, by contrast, where population growth was sharply slowing down towards the end of the nineteenth century, it might have become easier to find a job and a decent dwelling, since competition in the labor and housing markets decreased. Most likely, it was a combination of structural changes in the labor and housing markets and differences in societal openness, which explain the divergent trend in chances for social inclusion in Antwerp and Stockholm.

This reasoning is in line with other observations on processes of social inclusion and exclusion through time and space. In times in which there is no or limited competition between natives and migrants, newcomers are welcomed and it is relatively easy for them to acquire a position in the receiving society. This changes dramatically in times of economic decay, when the chances in the labor market decline and the attitude of the native population becomes more negative towards newcomers. In those periods migrants are often considered as a threat and barriers are constructed in order to limit the influx of migrants (Lucassen, 2005). It is logical than in such times social inclusion is more difficult to attain and that social exclusion occurs more frequently.

The surplus value of this study lies in part in its comparative perspective. Most studies in the field rather focus on the social inclusion process of a specific group of migrants in a single city. Such studies lack, however, a certain dimension. Comments on the impact of contextual factors like societal openness, labor and housing market characteristics and demographic structures become more meaningful, once differences and similarities between and within groups of migrants in different cities are identified. The good news is that this type of migration and social inclusion and exclusion research will be facilitated by initiatives like the one of the European Historical Population Samples Network (ESF, 2011). ${ }^{6}$ By offering scholars a common format and a common interface to a wide range of databases with longitudinal demographic data on individuals, families and households, the possibilities for comparative longitudinal research on migration and social inclusion and exclusion in the past will be considerably widened.

\section{Acknowledgements}

We would like to thank the Research Foundation Flanders (FWO), KU Leuven (Belgium), Umeå University (Sweden), The Royal Swedish Academy of Letters, History and Antiquities (Kungl. Vitterhetsakademien) and NCCR Lives (Switzerland) for their research grants, which made this 
research possible. We are also grateful to the Max Planck Institute for Demographic Research in Rostock (Germany) as they financed and facilitated the Urban Demography Network meetings, which led to the publication of this special issue. Moreover, we are indebted to the research network Historical Demography (FWO). Next, we want to thank Erik Vanhoute and Sven Vrielinck (UGent) for providing us with population figures from the LOKSTAT database. Last but not least, we would like to thank Jan Kok (Radboud University Nijmegen \& KU Leuven) and Leo Lucassen (Leiden University) and Mikolaj Szoltysek (Max Planck Institute for Demographic Research in Rostock) and Arne Solli (University of Bergen) for their useful comments and suggestions.

\section{Notes}

1. Participation in political and cultural activities, as well as access to (public) education, health care and the social security system, are often also included in definitions on social inclusion and exclusion (Odmivar \& Richmond, 2003; Sen, 2000), but since this is outside the scope of this article, we have narrowed our definition.

2. Alba and Nee (2003) underline that assimilation (in the way they use the concept) does not only change the cultural practices, attitudes and behavior of the immigrant group. Immigration also transforms the host society and that is also an outcome of the assimilation process.

3. Another type of restriction on marriage was directed towards partners who shared blood ties. Incest was one of the sins which had to be avoided in order to avoid disgrace within the community.

4. The diamond industry, which was dominated by the Jewish community, is an important exception.

5. Gothenburg was and stayed Sweden's main port city.

6. http://www.ehps-net.eu/

7. Including suburbs of Berchem, Borgerhout, Deurne, Hoboken, Merksem and Wilrijk.

\section{References}

Ahlenius, K., \& Kempe, A. (1909). Sverige: geografisk, topografisk, statistisk beskrifning. D.4, Södermanlands, Stockholms och Uppsala län samt Stockholm. Stockholm: Wahlström \& Widstrand.

Alba, R., \& Nee, V. (2003). Remaking the American mainstream: Assimilation and contemporary immigration. Cambridge, Mass.: Harvard University Press.

Alter, G. (1988). Family and the female life course. The Women of Verviers, Belgium, 1849-1880. Madison: The University of Wisconsin Press.

Böcker, A. (1994). Chain migration over legally closed borders: Settled migrants as bridgeheads and gatekeepers. Netherlands' Journal of Social Sciences, 30, 87-106.

Bouman, P., \& Bouman, W. (1955). De groei van de grote werkstad. Eens studie over de bevolking van Rotterdam. Assen: Van Gorcum \& Comp.

Chakravarty, S., \& Ambrosio, C. (2006). The measurement of social exclusion. Review of Income and Wealth, 52, 377-398.

Darroch, G. (1981). Migrants in the nineteenth century: Fugitives or families in motion? Journal of Family History, 6, 257-277.

De Brabander, G. (1986). De explosieve ontwikkeling van een agglomeratie. In K. Van Isacker \& R. Van Uyten (Eds.), Twaalf eeuwen geschiedenis en cultuur (pp. 352-361). Antwerp: Mercatorfonds.

De Goey, F. (2004). Comparative port history of Rotterdam and Antwerp (1880-2000): Competition, cargo and costs. Amsterdam: Aksant.

De Haas, H. (2003). Migration and development in Southern Morocco. The disparate socioeconomic impacts of out-migration on the Todgha Oasis Valley. (Unpublished Ph.D. Thesis) Radboud University, Nijmegen.

De Vries, J. (1984). European urbanization, 1500-1800. London: Routledge.

Dribe, M., Manfredini, M., Oris, M., \& Ritschard, G. (2010). Access to reproduction in pretransitional Europe. A sequential approach. Paper presented at the conference on Marriage Patterns, Household Formation and Economic Development organized by the Centre for Global Economic History at Utrecht University. 
Ekamper, P., Van Poppel, F., \& Mandemakers, K. (2011). Widening horizons? The geography of the marriage market in nineteenth and early twentieth century Netherlands. In M. Guttmann, G. Deane, E. Merchant \& K. Sylvester (Eds.), Navigating time and space in population studies. Dordrecht: Springer.

ESF. (2011). Research Networking Programme. European Historical Population Samples Network (EHPS-Net). Strasbourg: Humanities and Social Sciences Unit, European Science Foundation.

Geschwind, A., \& Fogelvik, S. (2000). Sweden: The Stockholm historical database. In P. Hall, R. McKaa \& G. Thorvaldsen (Eds.), Handbook of international microdata for population research (pp. 207-231). Minneapolis, MN: IMAG, Minnesota Population Center.

Greefs, H. (2008). Exploiting international webs of relations: Immigrants and the reopening of the harbour of Antwerp on the eve of the nineteenth century. In A. Jarvis \& R. Lee (Eds.), Trade, migration and urban networks in port cities, 1640-1940 (pp. 81-107). St. John's: International Maritime Economic History Association.

Gutmann, M., \& Van de Walle, E. (1978). New sources for social and demographic history: The Belgian population registers. Social Science History, 2, 121-143.

Hajnal, J. (1965). European marriage patterns in perspective. In D. V. Glass \& D. E. C. Eversley (Eds.), Population in history (pp. 101-143). London: Arnold.

Hajnal, J. (1983). Two kinds of pre-industrial household formation system. In R. Wall, J. Robin \& P. Laslett (Eds.), Family forms in historic Europe (pp. 65-104). Cambridge: Cambridge University Press.

Handlin, O. (1951). The uprooted. The epic story of the great migrations that made the American people. Boston: Little Brown.

Hayes, A., Gray, M., \& Edwards, B. (2008). Social inclusion: Origin, concepts and key themes. Paper prepared for the Social Inclusion Unit, Department of Prime Minister and Cabinet of the Australian Government.

Head-König, A. (1993). Forced marriages and forbidden marriages in Switzerland: State control of the formation of marriage in catholic and protestant cantons in the eighteenth and nineteenth centuries. Continuity and Change, 8, 441-465.

Hochstadt, S. (2002). Mobility and modernity. Migration in Germany 1820-1989. Ann Arbor: The University of Michigan Press.

Högberg, S. (1981). Stockholms historia. Småstaden. Fabriksstaden. Storstaden. Stockholm: Bonnier Fakta.

Hoste, S., \& Loyen, R. (2002). "Sauvons Anvers!" De maritieme toegangsweg van de haven van Antwerpen vanuit bedrijfshistorisch perspectief (1870-1940). NEHA-Jaarboek, 65, 169-200.

Jackson, J. (1997). Migration and urbanization in the Ruhr Valley, 1821-1914. Boston: Humanities Press.

Kertzer, D., \& Hogan, D. (1985). On the move: Migration in an Italian community, 1865-1921. Social Science History, 9(1), 1-23.

Knodel, J. (1967). Marriage and illegitimacy in nineteenth-century Germany. Population Studies, 20, 279-294.

Kok, J. (2006). "Eigen baas zijn da's maar alles". Huwelijksmotieven van Rotterdammers uit de tweede helft van de negentiende eeuw. In P. van de Laar, L. Lucassen \& K. Mandemakers (Eds). Immigratie en levensloop in Rotterdam vanaf het einde van de negentiende eew. Amstedam: Aksant.

Lee, R. (1999). Urban labor-markets, in-migration, and demographic growth: Bremen 1815-1914. Journal of Interdisciplinary History, 30, 437-473.

Lee, R., \& Lawton, R. (2002). Port development and the demographic dynamics of European urbanization. In R. Lawton \& R. Lee (Eds.), Population and society in Western European port cities c.1650-1939 (pp. 1-36). Liverpool: Liverpool University Press.

Lesger, C., Lucassen, L., \& Schrover, M. (2002). Is there life outside the migrant network? German immigrants in XIXth century Netherlands and the need for a more balanced migration typology. Annales de Démographie Historique, 2, 29-50.

Lis, C. (1986). Social change and the labouring poor: Antwerp, 1770-1860. New Haven: Yale University Press.

Lucassen, L. (2004). De selectiviteit van blijvers. Tijdschrift voor sociale en economische geschiedenis, 1, 92-115.

Lucassen, L. (2005). The immigrant threat: The integration of old and new migrants in Western Europe since 1850. Urbana and Chicago: University of Illinois Press. 
Lucussen, J., \& Lucassen, L. (2009). The mobility transition revisited, 1500-1900: What the case of Europe can offer to global history. Journal of Global History, 4, 347-377.

Lucassen, L., Feldman, D., \& Oltmer, J. (2006). Drawing up the balance sheet. In L. Lucassen, D. Feldman \& J. Oltmer (Eds.), Paths of integration. Migrants in Western Europe 1880-2004. Amsterdam: Amsterdam University Press.

Lynch, K. (1991). The European marriage pattern in the cities: Variations on a theme by Hajnal. Journal of Family History, 16, 79-95.

Matovic, M. R. (1986). The Stockholm marriage: Extra-legal family formation in Stockholm 18601890. Continuity and Change, 1, 385-4143.

Matthijs, K. (2001). De mateloze negentiende eeuw. Bevolking, huwelijk, gezin en sociale verandering. Leuven: Universitaire Pers Leuven.

Matthijs, K., \& Moreels, S. (2010). The Antwerp COR *-database: A unique Flemish source for historical-demographic research. History of the Family, 15, 109-115.

Moch, L. (2003). Moving Europeans. Migration in Western Europe since 1650. Bloomington \& Indianapolis: Indiana University Press.

Neumann, G., \& Topel, R. (1991). Employment risk, diversification, and unemployment. The Quarterly Journal of Economics, 106, 1341-1365.

Odmivar, R., \& Richmond, T. (2003). Immigrant settlement and social inclusion in Canada. Working Paper Series. Perspectives on Social Inclusion, January 2003.

Oris, M. (2000). The age at marriage of migrants during the industrial revolution in the region of liège. The History of the Family, 5, 391-413.

Papillion, M. (2002). Immigration, diversity and social inclusion in Canada's cities. Discussion Paper F//27 Family Network.

Park, R. (1928). Human migration and the marginal man. American Journal of Sociology, 33, $881-893$.

Park, R., \& Burgess, E. (1925). The city. Chicago: University of Chicago Press.

Pooley, C., \& Turnbull, J. (1997). Migration and mobility in Britain since the $18^{\text {th }}$ century. London: Routledge.

Saerens, L. (2000). Vreemdelingen in een wereldstad. Een geschiedenis van Antwerpen en zijn Joodse beveling. Tielt: Lannoo.

Schumacher, R., Ryckzkowka, G., \& Perroux, O. (2007). Unwed mothers in the city. Illegitimate fertility in $19^{\text {th }}$-century Geneva. History of the Family, 12, 189-202.

Sen, A. (2000). Social exclusion: Concept, application, and scrutinity. Social Development Paper, (No. 1), 1-54.

Sewell, W. (1985). Structure and mobility. The men and women of Marseille, 1820-1870. Cambridge: Cambridge University Press.

Statistiska Centralbyrån. (1878-1912). Bidrag till Sveriges officiella statistik. D, Kommerskollegii underdåniga berättelse för år .... Stockholm: P. A. Norstedt \& söner.

Statistiska Centralbyrån. (1900). Bidrag till Sveriges officiella statistik. A, Befolkningsstatistik. Stockholm: P. A. Norstedt \& söner.

Statistiska Centralbyrån. (1914-1928). Statistisk årsbok för Sverige. Stockholm: P. A. Norstedt \& söner.

Thernstrom, S. (1973). The other bostonians. Poverty and progress in the American metropolis 1880-1970. Cambridge (Mass.)/ London (England): Harvard University Press.

Van Baelen, H. (2007). Constructie van een historisch-demografisch longitudinale database. Leuven: Centre for Sociological Research.

Van de Putte, B. (2003). Homogamy by geographical origin: Segregation in nineteenth-century Flemish cities (Gent, Leuven, and Aalst). Journal of Family History, 28, 364-390.

Van de Putte, B. (2005). Partnerkeuze in de 19de eeuw: klasse, geografische afkomst, romantiek en de vorming van sociale groepen op de huwelijksmarkt. Leuven: Universitaire pers Leuven.

Van den Eerenbeemt, H. (1977). Armoede en arbeidsdwang. Werkinrichtingen voor "onnutte" Nederlandsers in de Republiek 1760-1795. Een Mentaliteitsgeschiedenis. The Hague: Martinus Nijhoff.

Van Leeuwen, M., \& Maas, I. (2011). HISCLASS: A historical social class scheme. Leuven: Leuven University Press.

Van Poppel, F. (1992). Trouwen in Nederland. Een historisch-demografische studie van de 19e en vroeg-20e eeuw. Wageningen: Landbouwuniversiteit Wageningen. 
Wingens, M., de Valk, H. A. G., Windzio, M., \& Aybek, C. (2011). The sociological life course approach and research on migration and integration. In M. Wingens, M. Windzio, H. de Valk \& C. Aybek (Eds.), A life course perspective on migration and integration (pp. 1-26). Dordrecht: Springer.

Winter, A. (2009). Migrants and urban change: Newcomers to Antwerp, 1760-1860. London: Pickering \& Chatto. 